Provided for non-commercial research and education use. Not for reproduction, distribution or commercial use.

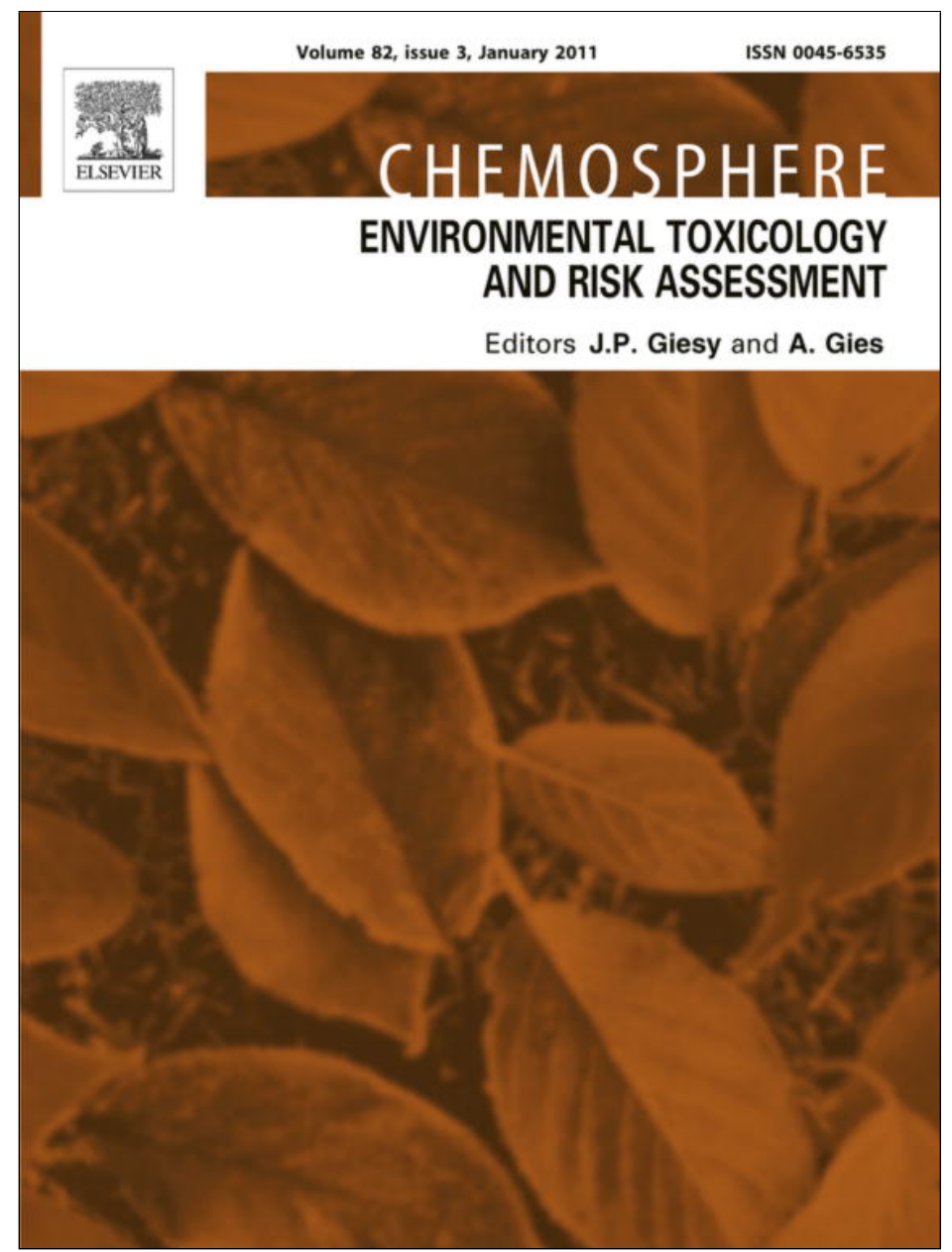

This article appeared in a journal published by Elsevier. The attached copy is furnished to the author for internal non-commercial research and education use, including for instruction at the authors institution and sharing with colleagues.

Other uses, including reproduction and distribution, or selling or licensing copies, or posting to personal, institutional or third party websites are prohibited.

In most cases authors are permitted to post their version of the article (e.g. in Word or Tex form) to their personal website or institutional repository. Authors requiring further information regarding Elsevier's archiving and manuscript policies are encouraged to visit:

http://www.elsevier.com/copyright 


\title{
Secretion profiles of fungi as potential tools for metal ecotoxicity assessment: A study of enzymatic system in Trametes versicolor
}

\author{
Jérémie D. Lebrun ${ }^{\mathrm{a}, \mathrm{b}, *}$, Nathalie Demont-Caulet ${ }^{\mathrm{c}, \mathrm{d}}$, Nathalie Cheviron ${ }^{\mathrm{a}}$, Karine Laval ${ }^{\mathrm{b}}$, \\ Isabelle Trinsoutrot-Gattin ${ }^{\mathrm{b}}$, Christian Mougin ${ }^{\mathrm{a}}$
}

a INRA, UPR 251 Physico-chimie et Ecotoxicologie des SolS d'Agrosystèmes Contaminés, Route de St Cyr, 78026 Versailles, France

${ }^{\mathrm{b}}$ ESITPA, Laboratoire BioSol, 3 rue du Tronquet, 76134 Mont-St-Aignan, France

${ }^{c}$ Université Paris-Diderot, UFR Sciences du Vivant, 35 rue Hélène Brion, 75205 Paris, France

d INRA, UPR 501 Biologie Cellulaire, Route de St Cyr, 78026 Versailles, France

\section{A R T I C L E I N F O}

\section{Article history:}

Received 26 April 2010

Received in revised form 27 September

2010

Accepted 3 October 2010

Available online 25 October 2010

\section{Keywords:}

Hydrolases

Ligninolytic oxidases

Laccase

Secretome

Biomarkers

Metal cocktail

\begin{abstract}
A B S T R A C T
The relationship between the expression of extracellular enzymatic system and a metal stress is scarce in fungi, hence limiting the possible use of secretion profiles as tools for metal ecotoxicity assessment. In the present study, we investigated the effect of $\mathrm{Zn}, \mathrm{Cu}, \mathrm{Pb}$ and $\mathrm{Cd}$, tested alone or in equimolar cocktail, on the secretion profiles at enzymatic and protein levels in Trametes versicolor. For that purpose, extracellular hydrolases (acid phosphatase, $\beta$-glucosidase, $\beta$-galactosidase and $\mathrm{N}$-acetyl- $\beta$-glucosaminidase) and ligninolytic oxidases (laccase, Mn-peroxidase) were monitored in liquid cultures. Fungal secretome was analyzed by electrophoresis and laccase secretion was characterized by western-blot and mass spectrometry analyses. Our results showed that all hydrolase activities were inhibited by the metals tested alone or in cocktail, whereas oxidase activities were specifically stimulated by $\mathrm{Cu}, \mathrm{Cd}$ and metal cocktail. At protein level, metal exposure modified the electrophoretic profiles of fungal secretome and affected the diversity of secreted proteins. Two laccase isoenzymes, LacA and LacB, identified by mass spectrometry were differentially glycosylated according to the metal exposure. The amount of secreted LacA and LacB was strongly correlated with the stimulation of laccase activity by $\mathrm{Cu}, \mathrm{Cd}$ and metal cocktail. These modifications of extracellular enzymatic system suggest that fungal oxidases could be used as biomarkers of metal exposure.
\end{abstract}

(c) 2010 Elsevier Ltd. All rights reserved.

\section{Introduction}

Metal contamination of the biosphere due to human activities has become a major environmental and health problem. The release of metals into the terrestrial ecosystems has led to their important accumulation in biota and often alters biological systems (Akmal et al., 2005; Boularbah et al., 2006). These non-biodegradable contaminants travel up the trophic chains and enter bioaccumulation processes (van Gestel, 2008). Thus, essential metals in excess as well as metals with no biological role can result in adverse effects for living organisms, and consequently on the terrestrial ecosystem functioning. However, the metal assessment of metal effects on biota remains a research subject because of the lack of efficient tools. Before performing studies taking into account the complex properties of soil, it is first necessary to characterize biological responses to a metal stress at the organism level in

* Corresponding author. Address: Unité HBAN, Parc de Tourvoie, BP 44, 92163 Antony Cedex, France. Tel.: +33 (0) 1409665 87; fax: +33 (0) 140966199

E-mail address: jeremie.lebrun@cemagref.fr (J.D. Lebrun). order to assess their relevance as tools for metal ecotoxicity assessment.

Since fungi represent one of the largest biomass in terrestrial ecosystems, the response of their extracellular enzymatic systems to metals offers promising perspectives for ecotoxicological assessment, providing the mechanisms of metal action are well known. By their ability to adapt their metabolism to various nutrient sources, saprophytic fungi are key colonizers of ecological niches and play a major role in the terrestrial ecosystem functioning (Kjøller and Struwe, 2002; Bouws et al., 2008). These microorganisms produce extracellular enzymes involved in the nutrient mobilization and mineralization of biopolymers. Proteomic studies of the totality of secreted proteins, the secretome, have recently begun to emerge in fungi (Kim et al., 2007). Although a great number of extracellular proteins still remains to be identified, various types of hydrolases and oxidases were characterized. These approaches allowed to show the secretion profiles are modified by a saline stress (Gori et al., 2007; Liang et al., 2007). However, saprophytic fungi considered as the predominant degraders of lignin, have been rather studied for their set of ligninolytic oxidases, such as laccases or peroxidases, for biotechnological, industrial and environmental 
applications (Mougin et al., 2003; Novotný et al., 2009). In spite of these investigations, the characterization of differential expressions of extracellular enzymes under a metal stress is still limited in fungi.

Although fungi have mechanisms for metal tolerance, the activity of their extracellular enzymes can be modulated during metal exposure (Baldrian, 2003). Metals, such as $\mathrm{Cu}, \mathrm{Zn}$, Mn or Pb, modify the activity of cellulolytic hydrolases and ligninolytic oxidases in Pleurotus ostreatus (Baldrian et al., 2006). Cu is known to increase the extracellular laccase in different filamentous fungi (Crowe and Olsson, 2001; Baldrian, 2003; Baldrian et al., 2006). This oxidase response to metals has been explained at transcriptional level. Collins and Dobson (1997) showed that the stimulation of laccase activity by $\mathrm{Cu}$ corresponds to an increase in its mRNA in Trametes versicolor. It has also been observed that laccase can be induced as different glycosylated isoforms after exposure to 2,5-xylidine, a well known inducer of fungal laccases (Bertrand et al., 2002a; Kollmann et al., 2005). To our knowledge, such post-translational modifications have not been observed after metal exposures. Furthermore, fungi secrete isoenzymes of oxidases, i.e. enzymes catalyzing the same reactions but exhibiting different sequences in amino acids (Cassland and Jönsson, 1999; Necochea et al., 2005). Thus, differential expressions of enzymes or isoenzymes under a metal stress could provide fungal biomarkers of exposure. By an inoculation strategy, it is feasible to use fungi and their enzymatic system in bioassay studies. For example, hydrolytic and ligninolytic enzyme activities were monitored after inoculation of fungi in soils contaminated by $\mathrm{Pb}$ (Kähkönen et al., 2008).

In the present study, we investigated the effect of metals on secretion profiles in an efficient lignin-degrading fungus, $T$. versicolor, at enzymatic and protein levels. The fungus was exposed to essential metals, $\mathrm{Zn}$ or $\mathrm{Cu}$, and non-essential metals, $\mathrm{Pb}$ or $\mathrm{Cd}$ in liquid cultures. Exposures with metal cocktails were performed in order to reflect multiple contaminations, which is rarely realized in the literature. At enzymatic level, we monitored the activities of two main enzyme families involved in the terrestrial ecosystem functioning, hydrolases (acid phosphatase, $\beta$-glucosidase, $\beta$-galactosidase and $\mathrm{N}$-acetyl- $\beta$-glucosaminidase) and ligninolytic oxidases (laccase, Mn-peroxidase). At protein level, a comparative analysis in electrophoresis of total extracellular proteins was carried out to provide an overview of secretion profiles. The laccase secretion was characterized by western-blot and mass spectrometry analyses.

\section{Material and methods}

\subsection{Culture conditions and metal exposures}

Trametes versicolor ATCC 32745 was grown on a liquid culture medium, containing maltose and ammonium tartarate as carbon and nitrogen sources (Lesage-Meessen et al., 1996). A mycelium mat on agar plugs ( $10 \mathrm{~mm}$ diam.) was inoculated into $10 \mathrm{~mL}$ of culture medium in $150 \mathrm{~mL}$ Erlenmeyer flasks. Cultures were carried out statically in the dark at $25^{\circ} \mathrm{C}$. After $3 \mathrm{~d}$ of incubation, $100 \mu \mathrm{L}$ of $\mathrm{ZnSO}_{4}, \mathrm{CuSO}_{4}, \mathrm{CdSO}_{4}$ or $\mathrm{PbCl}_{2}$ sterilized by filtration $(0.2 \mu \mathrm{m}$ pore size membrane) were added into liquid cultures at final concentrations of 0.25 or $1 \mathrm{mM}$. Experiments with cocktails of four metals in equimolarity were realized at final concentrations of 0.25, 1 and $4 \mathrm{mM}$. Controls were done without added metal. The experiments were carried out with three independent replicates per treatment.

After $5 \mathrm{~d}$ of metal exposure, mycelia were harvested by a nylon screen $(40 \mu \mathrm{m})$ and dried for $48 \mathrm{~h}$ at $80^{\circ} \mathrm{C}$ to determine the fungal biomass. The mycelium free culture was filtrated through a $0.2 \mu \mathrm{m}$-filter and used for the extracellular enzymatic assays, the quantification of secreted proteins by the Bradford method using bovine serum albumin as a standard (Bradford, 1976) and the protein preparation for electrophoresis.

\subsection{Enzymatic assays}

Acid phosphatase (EC 3.1.3.2), $\beta$-glucosidase (EC 3.2.1.21), $\beta$-galactosidase (EC 3.2.1.23), and $\mathrm{N}$-acetyl- $\beta$-glucosaminidase (EC 3.2.1.30) activities were assayed using their respective substrates of conjugated p-nitrophenol (Sigma-Aldrich). Assays were carried out in 96-well microplates by mixing $160 \mu \mathrm{L}$ of substrate solution $(25 \mathrm{mM})$ in citrate/phosphate buffer or $\mathrm{CPB}(\mathrm{pH} 4.5,0.1 \mathrm{M})$ with $40 \mu \mathrm{L}$ of enzymatic samples, followed by incubation at $37^{\circ} \mathrm{C}$. After $45 \mathrm{~min}, 50 \mu \mathrm{L}$ of $\mathrm{Na}_{2} \mathrm{CO}_{3}(1 \mathrm{M})$ was added to stop the reaction. The liberation of p-nitrophenol by enzymatic hydrolysis of the substrate was determined at $405 \mathrm{~nm}$ (Keshri and Magan, 2000). The standard solutions of p-nitrophenol were treated in the same way as samples.

Laccase (EC 1.10.3.2) and Mn-peroxidase (EC 1.11.1.14) activities were measured respectively by monitoring the oxidation of 2,2'-azinobis-(3-ethylbenzothiazoline-6-sulfonic) acid at $420 \mathrm{~nm}$ in CPB (0.1 M, pH 3.0) (Wolfenden and Willson, 1982) and the oxidation of 4-(4-hydroxy-3-methoxyphenyl)-3-buten-2-one at $334 \mathrm{~nm}$ in CPB $(0.1 \mathrm{M}, \mathrm{pH} 5.0)$ in the presence of $\mathrm{MnSO}_{4}$ and $\mathrm{H}_{2} \mathrm{O}_{2}$ (Paszczynski et al., 1986). Solutions of enzymes were added to a final volume of $1 \mathrm{~mL}$.

Activities were measured in triplicate and expressed in $\mathrm{Ug}^{-1}$ dry weight of fungal biomass. One unit of activity was defined as the amount of enzyme that catalyzed $1 \mu \mathrm{mol}$ substrate in $1 \mathrm{~min}$. Controls performed from boiled enzymatic extracts to inactive the activities were treated in the same way as the samples.

\subsection{Extracellular protein preparation for electrophoresis}

The extracellular filtrates were concentrated 100 -fold by an Amicon $10 \mathrm{kDa}$ filter at $4{ }^{\circ} \mathrm{C}$ and resuspended in $10 \mathrm{~mL}$ of Tris$\mathrm{HCl}$ buffer ( $\mathrm{pH} 6.8,50 \mathrm{mM}$ ) twice to remove salts. For protein precipitation, cold acetone with $0.07 \% \beta$-mercaptoethanol $\left(-20^{\circ} \mathrm{C}\right)$ were added in concentrated protein solutions $(3: 1 \mathrm{v} / \mathrm{v})$. After mixing and incubation of $30 \mathrm{~min}$ at $-20^{\circ} \mathrm{C}$, the samples were centrifuged at $14000 \mathrm{~g}$ for $10 \mathrm{~min}$. The pellets were washed with cold acetone and then air-dried. The dry protein pellets were dissolved in $200 \mu \mathrm{L}$ of a solution containing $2 \%$ SDS, $8 \mathrm{M}$ urea and $50 \mathrm{mM}$ Tris- $\mathrm{HCl}(\mathrm{pH} 6.8)$ and incubated $24 \mathrm{~h}$ at $4{ }^{\circ} \mathrm{C}$. The proteins were separated by SDS-PAGE (poly-acrylamide gel electrophoresis) using $4 \%$ stacking gel and $12.5 \%$ separating gel at $110 \mathrm{~V}$ with Mini-protean electrophoresis cell (Biorad) and proteins were stained using the Coomassie Blue standard method (Biorad). Glycosylated isoforms of laccases induced by exposure of $T$. versicolor to 2,5-xylidine were purified as described by Bertrand et al. (2002b) and used as controls for the laccase characterization. The molecular weights were estimated by comparison with a commercial protein mixture (Precision plus protein standards, Biorad). Electrophoresis gels were done from three independent sets.

\subsection{Protein characterization by western-blot and LC-MS/MS}

The proteins were electro-transferred $\left(0.8 \mathrm{~mA}\right.$ per $\mathrm{cm}^{2}$ of gel $)$ from the electrophoresis gel to a nitrocellulose membrane using a Trans-blot cell (Biorad). Detection of laccase on the membrane was performed with rabbit anti-bodies in combination with goat anti-rabbit Ig conjugated with alkaline phosphatase (Jolivalt et al., 2005). The intensity of revealed spots was quantified by imager (ImageQuant, Amersham) and related to the dry weight of fungal biomass. Western blots were done in triplicate.

Bands of interest were excised from SDS-PAGE. In-gel digestion was performed with the Progest system (Genomic Solution) 
according to a standard trypsinolysis protocol. Gel plugs were first washed twice with $10 \%(\mathrm{v} / \mathrm{v})$ acetic acid, $40 \%(\mathrm{v} / \mathrm{v})$ ethanol in water, and then with acetonitrile. They were further washed with $25 \mathrm{mM}$ $\mathrm{NH}_{4} \mathrm{CO}_{3}$ and dehydrated in acetonitrile (two alternating cycles). Digestion was performed for $6 \mathrm{~h}$ at $37^{\circ} \mathrm{C}$ with $125 \mathrm{ng}$ of modified trypsin (Promega) dissolved in $20 \%(\mathrm{v} / \mathrm{v})$ methanol in $20 \mathrm{mM}$ $\mathrm{NH}_{4} \mathrm{CO}_{3}$. Tryptic peptides were first extracted with $50 \%(\mathrm{v} / \mathrm{v})$ acetonitrile, $0.5 \%$ trifluoroacetic acid in water, and then with pure acetonitrile. Both peptide extracts were pooled, dried in a vacuum speed concentrator and suspended in $25 \mu \mathrm{L}$ of $2 \%(\mathrm{v} / \mathrm{v})$ acetonitrile, $0.08 \%$ $(\mathrm{v} / \mathrm{v})$ trifluoroacetic acid in water.

LC-MS/MS analysis was performed on Ultimate 3000 LC system (Dionex, France) connected to a LTQ-Orbitrap Discovery mass spectrometer (Thermo Fisher, USA) via a nanoelectrospray ion source. After $4 \mathrm{~min}$, the precolumn was connected to the separating nanocolumn Pepmap C18 $(0.075 \times 15 \mathrm{~cm}, 100 \AA, 3 \mu \mathrm{m})$ and the linear gradient was started from $2 \%$ to $36 \%$ of buffer B ( $80 \%$ acetonitrile, $0.1 \%$ formic acid) in buffer $\mathrm{A}$ ( $2 \%$ acetonitrile, $0.1 \%$ formic acid) at $300 \mathrm{~nL} \mathrm{~min}-1$ over $50 \mathrm{~min}$. The doubly and the triply charged precursor ions were subjected to MS/MS fragmentation with a 3-min exclusion window, and with classical peptide fragmentation parameters.

In the absence of data on $T$. versicolor, protein identification was performed querying MS/MS data against a fungi protein database (http://www.ncbi.nlm.nih.gov/protein, 08.18.2009) together with an in-house contaminant database, using the X!Tandem software (X!Tandem Tornado 2008.02.01.3, http://www.thegpm.org) with the following parameters: one trypsin missed cleavage allowed, alkylation of cysteine and conditional oxidation of methionine, precursor and fragment ion set at $10 \mathrm{ppm}$ and $0.5 \mathrm{Da}$, respectively. A refined search was added with similar parameters except that semitryptic peptides and possible $\mathrm{N}$-ter acetylation of proteins were searched. All peptides matched with an E-value lower than 0.05 were parsed with an in-house program (http://PAPPSO.inra.fr/bioinformatique.html). Proteins identified with at least two unique peptides and $\log (E$-value) lower than $1 . E-8$ were validated.

\subsection{Statistical analyses}

Means and standard errors (SE) were calculated from three independent cultures for each measured biological variable. Statistical analyses were performed by XLStat (Addinsoft). The significant differences were tested with $P<0.05$.

\section{Results}

\subsection{Growth and protein secretion as affected by metals}

The ability of $T$. versicolor to grow in the presence of metals was monitored in liquid cultures. The results after $5 \mathrm{~d}$ of metal exposures are given in Fig. $1 \mathrm{~A}$. $\mathrm{Zn}$ and $\mathrm{Pb}$ did not significantly modify the biomass production of the fungus compared to the unexposed control. On the contrary, $\mathrm{Cu}$ and $\mathrm{Cd}$ had toxic effect at $1 \mathrm{mM}$ by decreasing the biomass production at $80 \%$ and $71 \%$ of control biomass respectively. The fungal exposure to metal cocktails at 1 and $4 \mathrm{mM}$ led to decrease in the fungal biomass about $81 \%$ and $77 \%$ respectively.

The quantification of total proteins secreted by T. versicolor after exposure to metals tested alone or in cocktail is shown in Fig. 1B. At $0.25 \mathrm{mM}$, metals had no significant effect on the amount of secreted proteins, except for $\mathrm{Cd}$. At $1 \mathrm{mM}, \mathrm{Zn}$ and $\mathrm{Pb}$ decreased the protein secretion about 2 -fold whereas $\mathrm{Cd}$ increased this secretion about 2.5-fold compared to the unexposed control. Without effect at $0.25 \mathrm{mM}$, the metal cocktails provided contrasted effects on the protein secretion for the highest concentrations. The amount of extracellular proteins was increased at $1 \mathrm{mM}$ whereas it was decreased at $4 \mathrm{mM}$.

\subsection{Functional responses to metals}

T. versicolor produced significant amounts of both extracellular hydrolases (acid phosphatase, $\beta$-glucosidase, $\beta$-galactosidase and $\mathrm{N}$-acetyl- $\beta$-glucosaminidase) and oxidases (laccase, Mnperoxidase) during liquid cultures. The production of these extracellular enzymes was modulated after $5 \mathrm{~d}$ of metal exposure (Fig. 2). These functional responses to metals differed according to the enzyme family. Concerning to the hydrolases, their production were decreased by all metals tested alone or in cocktail, but this response was not dose-dependent. Some metal exposures of T. versicolor led to no detections of hydrolase activities. In our conditions, no $\beta$-galactosidase activity was detected in the presence of $\mathrm{Pb}$ or the cocktail at $4 \mathrm{mM}$ and no $\mathrm{N}$-acetyl- $\beta$-glucosaminidase activity in the presence of $\mathrm{Pb}$ or $\mathrm{Cd}$ at $1 \mathrm{mM}$, or the cocktail at $4 \mathrm{mM}$. Concerning to the oxidases, their production was increased only by $\mathrm{Cu}, \mathrm{Cd}$ or metal cocktails. However, the sensitivity of oxidase response to metals depended on the concentration and considered enzyme. The laccase activity was stimulated from $0.25 \mathrm{mM}$ of $\mathrm{Cu}, \mathrm{Cd}$ or cocktail as dose-dependent way whereas the Mn-peroxidase activity was stimulated only from $1 \mathrm{mM}$.

\subsection{Electrophoretic profiles as affected by metals}

The total secreted proteins of T. versicolor exposed for $5 \mathrm{~d}$ to metals alone or in cocktail were run by electrophoresis. Electrophoretic profiles obtained for the highest concentrations are shown in Fig. 3. In the absence of metal, the protein separation in electrophoresis allowed to distinguish about 15 bands in our conditions. The majority of secreted proteins exhibited of molecular masses of $40-100 \mathrm{kDa}$. The metal exposures led to the modifications of electrophoretic profiles compared to the control. In the presence of $\mathrm{Cu}$, the intensity of the $50 \mathrm{kDa}$-band is strongly increased. In the case of $\mathrm{Pb}$, we can observe a decrease in the diversity of secreted proteins with the disappearance of bands. This decrease was more important in the presence of cocktail at $4 \mathrm{mM}$. In all culture conditions, a $59 \mathrm{kDa}$-band corresponding to that of purified laccase isoforms induced by xylidine was observed.

\subsection{Characterization of laccase secretion}

The laccase secretion was characterized by western-blot analysis (Fig. 4). Results confirmed the presence of laccase around $59 \mathrm{kDa}$. A slight difference of $5 \mathrm{kDa}$ was observed according to the metal exposure. At $4 \mathrm{mM}$, the metal cocktail gave two spots suggesting the presence of laccases differentially glycosylated, as observed with laccase isoforms induced by xylidine. It is noted the appearance of another laccase at around $50 \mathrm{kDa}$ whose the migration is slightly affected by the metal exposure. In the absence of metal, the quantification of spots by imager (Fig. 4B) showed that the $59 \mathrm{kDa}$-laccase is 5 -fold more secreted than the $50 \mathrm{kDa}-$ laccase. The spot intensity of these two laccase isoenzymes was notably increased in the presence of $\mathrm{Cu}, \mathrm{Cd}$ and metal cocktails.

The 59 and $50 \mathrm{kDa}$-bands from electrophoresis gels were analyzed by using LC-MS/MS allowing to identify of two laccase isoenzymes. The $59 \mathrm{kDa}$-band corresponded to a sequenced laccase isoenzyme of type A, called LacA (accession number D13372), and the $50 \mathrm{kDa}$-band to laccase isoenzyme of type B, called LacB (accession number U44430). The characteristic peptides of each isoenzyme are given in Table 1 . They covered $21 \%$ and $27.9 \%$ of protein sequences of LacA and LacB respectively. 

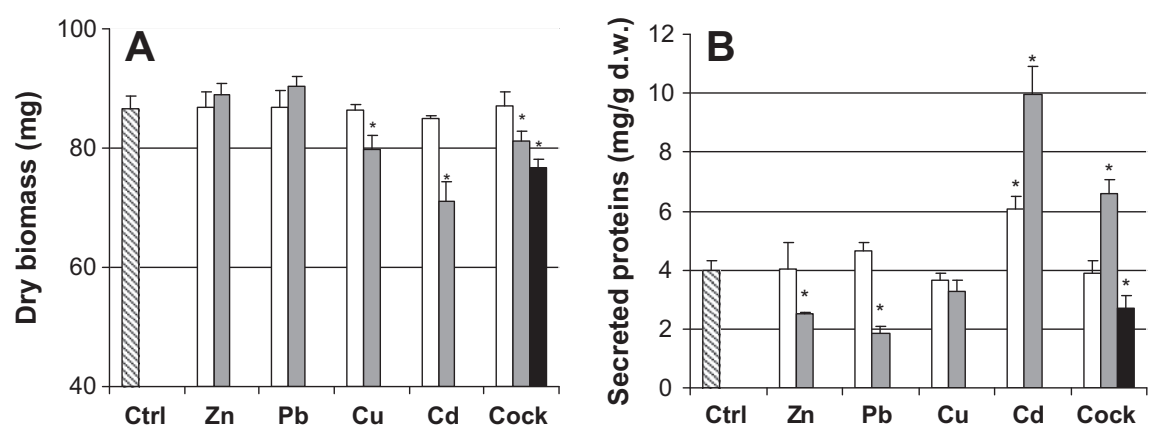

Fig. 1. Fungal biomass (A) and total proteins secreted (B) by Trametes versicolor exposed for $5 \mathrm{~d}$ to $\mathrm{Zn}$, Pb, Cu or $\mathrm{Cd}$ tested alone or in equimolar cocktail. Symbols: final concentrations of $0.25(\square), 1(\square)$ or $4 \mathrm{mM}(\square)$. The values are mean \pm SE for triplicate cultures $\left({ }^{*} P<0.05\right)$.
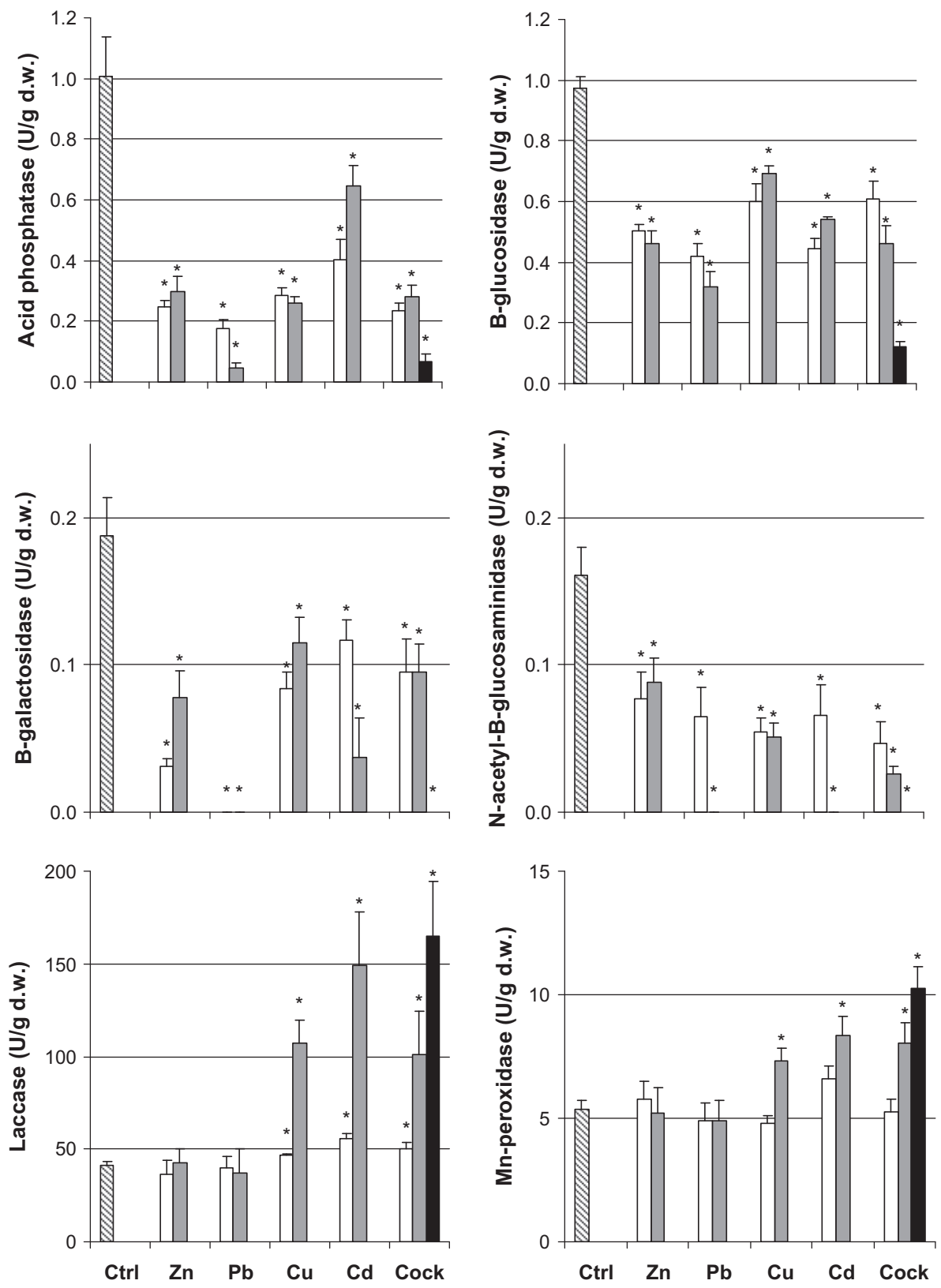

Fig. 2. Response of extracellular hydrolases and oxidases of Trametes versicolor exposed for $5 \mathrm{~d}$ to $\mathrm{Zn}$, Pb, $\mathrm{Cu}$ or $\mathrm{Cd}$ tested alone or in equimolar cocktail. Symbols: final concentrations of $0.25(\square), 1(\square)$ or $4 \mathrm{mM}(\square)$. The values are mean \pm SE for triplicate cultures $\left({ }^{*} P<0.05\right)$. 


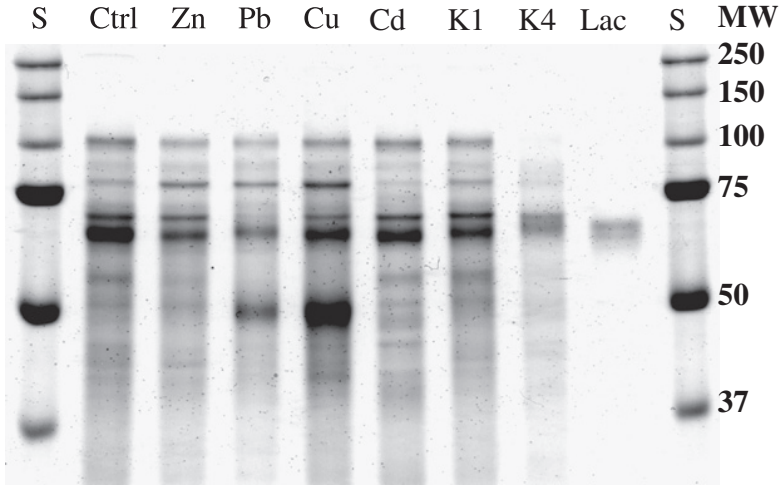

Fig. 3. Electrophoresis analysis of secretomes of Trametes versicolor exposed for $5 \mathrm{~d}$ to $\mathrm{Zn}, \mathrm{Pb}, \mathrm{Cu}$, or $\mathrm{Cd}$ at $1 \mathrm{mM}$ or metal cocktails at 1 (K1) or $4 \mathrm{mM}(\mathrm{K} 4) .1 / 10$ of total secreted proteins for each culture conditions were run in electrophoresis gel (12.5\%). Symbols: S, standard proteins; Lac, glycosylated laccase isoforms induced by xylidine.

A

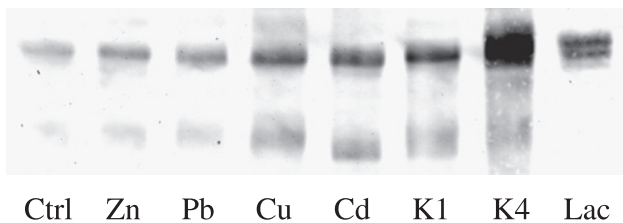

B

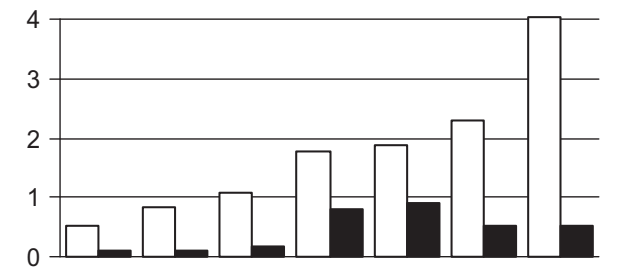

Fig. 4. Western blot analysis of laccases (A) and quantification by imager (B) of $59 \mathrm{kDa}(\square)$ and $50 \mathrm{kDa}$-laccase ( $\boldsymbol{\square})$ isoenzymes of Trametes versicolor exposed for $5 \mathrm{~d}$ to $\mathrm{Zn}, \mathrm{Pb}, \mathrm{Cu}$, or $\mathrm{Cd}$ at $1 \mathrm{mM}$ or metal cocktails at 1 (K1) or $4 \mathrm{mM}$ (K4). Lac, glycosylated laccase isoforms induced by xylidine.

Table 1

Characteristic peptides of two laccase isoenzymes identified by mass spectrometry from unexposed cultures of Trametes versicolor.

\begin{tabular}{llll}
\hline Sequence & E-value & Mass (Da) & $\begin{array}{l}\text { Accession } \\
\text { no. }\end{array}$ \\
\hline $\begin{array}{l}\text { Type A } \\
\text { STSIHWHGFFQK }\end{array}$ & & 55826 & $\begin{array}{l}\text { D13372 } \\
\text { (T. versicolor) }\end{array}$ \\
LGPAFPLGADATLINGK & 0.00017 & 1473.7 & \\
SAGSTVYNYDNPIFR & $2.2 \mathrm{e}-006$ & 1653.9 & \\
SPSTTTADLSVISVTPGK & 0.0036 & 1702.8 & \\
SPSTTTADLSVISVTPGKR & $7.3 \mathrm{e}-006$ & 1759.9 & \\
ANPNFGNVGFTGINSAILR & $6.7 \mathrm{e}-011$ & 1916.0 & \\
QAVVVNGGTPGPLITGNMGDR & $6.2 \mathrm{e}-008$ & 2018.0 & \\
Type B & 0.017 & 2068.1 & \\
MPVPGSPTPGGVDK & & 55771 & U44430 \\
FPLGADATLINGLGR & & & \\
DAIVVNGVVPSPLITGK & 0.00049 & 1353.6 & $($ T. versicolor $)$ \\
SASTPTAALAVINVQHGK & $3.6 \mathrm{e}-006$ & 1513.8 & \\
SASTPTAALAVINVQHGKR & $7.4 \mathrm{e}-006$ & 1677.9 & \\
ANPNFGTVGFAGGINSAILR & $2.8 \mathrm{e}-007$ & 1763.9 & \\
YDVDNESTVITLTDWYHTAAR & $3.8 \mathrm{e}-008$ & 1920.0 & \\
YQGAPVAEPTTTTPSVIPLIETNLHPLAR & $7.2 \mathrm{e}-007$ & 2469.1 & \\
\hline
\end{tabular}

\section{Discussion}

The improvement of knowledge on the functional diversity of fungal communities contribute to progress in the understanding of terrestrial ecosystem functioning. Saprophytic fungi were particularly studied for their ligninolytic enzyme set. However, the knowledge about both their extracellular hydrolases and functional diversity is still limited. Our results showed that T. versicolor produces extracellular hydrolases (acid phosphatase, $\beta$-glucosidase, $\beta$-galactosidase and $\mathrm{N}$-acetyl- $\beta$-glucosaminidase) involved in the cycling of phosphorus and the degradation of natural polymers such as cellulose and chitin. This fungus known for its lignin-degrading efficiency is thus able to use other nutrient sources. Despite a toxic effect of $\mathrm{Cu}$ and $\mathrm{Cd}$ at high concentrations, T. versicolor was tolerant to metals suggesting its ability to grow in environment contaminated by metals. It is known that fungi have adaptation mechanisms to different stresses including metal exposures (Baldrian, 2003). Thus, fungi have ecological interests for the development of exposure biomarkers to metals in terrestrial ecosystems.

In this present study, we hypothesized that protein differential secretions can be induced by environmental contaminants in fungi. The impact of metals on the extracellular enzymatic system of $T$. versicolor was assessed by exposures to essential or no biological role metals tested alone or in cocktail, more representative of multiple contaminations of ecosystems. In our conditions, all tested extracellular hydrolase activities of $T$. versicolor were decreased by $\mathrm{Zn}, \mathrm{Pb}, \mathrm{Cu}$ or $\mathrm{Cd}$ after $5 \mathrm{~d}$ exposures. But this response was not dose-dependent. $\mathrm{Pb}$ exhibited the strongest inhibitive effect with $75 \%$ and $91 \%$ average inhibitions of all tested hydrolase activities at 0.25 and $1 \mathrm{mM}$ respectively. This average inhibitive effect of other metals, $\mathrm{Zn}, \mathrm{Cu}$ and $\mathrm{Cd}$ was ranged between $55 \%$ and $65 \%$. A decrease in activities of cellulolytic hydrolases has also been observed in the presence of $\mathrm{Cu}, \mathrm{Mn}$ and $\mathrm{Pb}$ in P. ostreatus (Baldrian et al., 2006). By contrast, oxidase activities-laccase and Mn-peroxidase-were specifically stimulated by $\mathrm{Cu}$ and $\mathrm{Cd}$ whereas $\mathrm{Zn}$ and $\mathrm{Pb}$ had no effect on these activities. The stimulation of laccase activity by $\mathrm{Cu}$ observed in different fungi (Crowe and Olsson, 2001; Baldrian et al., 2006) has been explained at transcriptional level in T. versicolor (Collins and Dobson, 1997). Furthermore, Metal Responsive Elements or MRE have been characterized on genes coding for laccases or peroxidases in various fungi, which confirms the sensitivity and selectivity of the oxidase response to some metals (Johansson and Nyman, 1996; Giardina et al., 1999).

In our conditions, the average inhibitions of tested hydrolase activities were $59 \%, 65 \%$ and $95 \%$ in $T$. versicolor exposed for $5 \mathrm{~d}$ to metals in cocktail at $0.25,1$ and $4 \mathrm{mM}$ respectively. The stimulation of oxidases was dose-dependant with a sensitivity varying according to the considered enzyme. Although testing metals in cocktail is an original approach, it is difficult to discriminate the part of each metal on these functional responses. Indeed, neither the total concentration of cocktails nor the concentration of each metal in the cocktails was correlated to the effect of a metal taken alone. There may be competition processes between the metals in their distribution in different fungal compartments, i.e. internalization/externalization processes (Hu et al., 2003). Nevertheless, the oxidase response to metal cocktails can be attributed to the presence of $\mathrm{Cd}$ and $\mathrm{Cu}$.

In order to obtain an overview of secretion profiles at protein level, a comparative analysis by electrophoresis of total secreted proteins was carried out under different metal stresses in $T$. versicolor (Fig. 3). This study provides for the first time a snapshot of major proteins secreted by T. versicolor. It is noted that the separation of extracellular proteins by monodirectional electrophoresis is limiting in our conditions, but our objective was not to identify the whole of extracellular proteins. In the absence of metal, the electrophoretic profiles showed a diversity of secreted proteins. In metal stress conditions, the fungal secretion profiles were altered. $\mathrm{Pb}$ at $1 \mathrm{mM}$ and metal cocktail at $4 \mathrm{mM}$ led to the most important decrease in the protein diversity. That was consistent with the 
decrease both in amount of total secreted proteins and in hydrolase activities. Thus, metals affect the regulation of protein secretion in the fungus. To confirm this metal impact, we chose to characterize the laccase secretion in $T$. versicolor because the regulation mechanisms of oxidases are better known than those of hydrolases. We identified two isoenzymes of laccase around 59 and $50 \mathrm{kDa}$, LacA (accession number D13372) and LacB (accession number U44430) respectively. Although the alignment of their protein sequences showed a similarity near 65\%, these two isoenzymes belong to distinct phylogenetic groups (Cassland and Jönsson, 1999; Necochea et al., 2005). LacA 5-fold more secreted than LacB in our culture conditions is known to be the major isoenzyme in T. versicolor (Cassland and Jönsson, 1999; Mougin et al., 2003 ) and to be induced by organic compounds such as xylidine (Bertrand et al., 2002a). Our results showed that metals could induce the production of LacA, but also that of LacB which is not yet described in the literature to our knowledge. We found a strong correlation between the total amounts of secreted laccase isoenzymes and the stimulation of laccase activity by $\mathrm{Cu}, \mathrm{Cd}$ and metal cocktails $\left(y=3.121 x ; R^{2}=0.89\right)$. We have said previously that metals can act at transcriptional level. However, this present study confirms that the metal action also leads to both the efficient translation and secretion of active laccase isoenzymes. Furthermore, glycosylated isoforms were observed for the two isoenzymes after metal exposure affecting their migration during the electrophoresis. The glycosylation is a post-translational process favoring the stability and proteolysis prevention of proteins (Yoshitake et al., 1993). In the presence of metal cocktail at $4 \mathrm{mM}$, an excess in glycosylation led to the appearance of two glycosylated isoforms for LacA. This isoenzyme is known to be inducible under different glycosylated isoforms by 2,5-xylidine in $T$. versicolor (Bertrand et al., 2002a).

In summary, fungi represent one of major biomass in terrestrial ecosystems and are essentials for their functioning. Among these microorganisms, $T$. versicolor produces hydrolases and oxidases involved in the biogeochemical cycles of nutrients. The exposure of the fungus to metals tested alone or in cocktails modifies the secretion of extracellular system at enzymatic and protein levels. Unlike hydrolases, the response of oxidases is specific to some tested metals. $\mathrm{Cu}, \mathrm{Cd}$ and metal cocktail modulate the secretion of laccase isoenzymes and affect the glycosylation process. The fact of a metal stress induces both differential expressions of enzymes or isoenzymes and appearances of glycosylated forms validate the hypothesis of fungal secretion profiles can be used as tools for metal ecotoxicity assessment. For this purpose, the fungal oxidases could be relevant biomarkers of metal exposures because of the selectivity of their response. By inoculation of fungi specialized in oxidase production in soils contaminated by metals, further studies should allow to assess the influence of complex properties on the response of fungal enzymatic system.

\section{Acknowledgements}

This research was supported by a grant from INRA and Région de Haute Normandie. Authors thank C. Jolivalt for valuable comments concerning to the characterization of laccase secretion. They are grateful to D. Chevret (Platform PAPPSO, INRA, Jouy-enJosas, France) for performing the protein identification by mass spectrometry.

\section{References}

Akmal, M., Jianming, X., Zhaojun, L., Haizhen, W., Huaiyang, Y., 2005. Effects of cadmium and lead nitrate on biomass and substrate utilization pattern of soil microbial communities. Chemosphere 60, 508-514.
Baldrian, P., 2003. Interactions of heavy metals with white-rot fungi. Enzyme Microb. Technol. 32, 78-91.

Baldrian, P., Valášková, V., Merhautová, V., Gabriel, J., 2006. Degradation of lignocellulose by Pleurotus ostreatus in the presence of copper, manganese, lead and zinc. Res. Microbiol. 156, 670-676.

Bertrand, T., Jolivalt, C., Briozzo, P., Caminade, E., Joly, N., Madzak, C., Mougin, C., 2002a. Crystal structure of a four-copper laccase complexed with an arylamine: insights into recognition and correlation with kinetics. Biochemistry 41, 73257333.

Bertrand, T., Jolivalt, C., Caminade, E., Joly, N., Mougin, C., Briozzo, P., 2002b. Purification and preliminary crystallographic study of Trametes versicolor laccase in its native form. Acta Crystallogr. D58, 319-321.

Boularbah, A., Schwarz, C., Bitton, G., Morel, J.L., 2006. Heavy metals contamination from mining sites in south Morocco: 1 . Use of a biotest to assess metal toxicity of tailings and soils. Chemosphere 63, 802-810.

Bouws, H., Wattenberg, A., Zorn, H., 2008. Fungal secretomes-nature's toolbox for white biotechnology. Appl. Microbiol. Biotechnol. 80, 381-388.

Bradford, M.M., 1976. A rapid and sensitive method for quantification of microgram quantities of protein utilizing the principle of protein-dye-binding. Anal. Biochem. 72, 248-254.

Cassland, P., Jönsson, L.J., 1999. Characterization of a gene encoding Trametes versicolor laccase A and improved heterologous expression in Saccharomyces cerevisiae by decreased cultivation temperature. Appl. Microbiol. Biotechnol. 52, 393-400.

Collins, P.J., Dobson, A.D.W., 1997. Regulation of laccase gene transcription in Trametes versicolor. Appl. Environ. Microbiol. 63, 3444-3450.

Crowe, J.D., Olsson, S., 2001. Induction of laccase activity in Rhizoctonia solani by antagonistic Pseudomonas fluorescens strains and a range of chemical treatments. Appl. Environ. Microbiol. 67, 2088-2094.

Giardina, P., Palmieri, G., Scaloni, A., Fontanella, B., Faraco, V., Cennamo, G., Sannia, G., 1999. Protein and gene structure of a blue laccase from Pleurotus ostreatus. Biochem. J. 341, 655-663.

Gori, K., Hébraud, M., Chambon, C., Mortensen, H.D., Arneborg, N., Jerpersen, L., 2007. Proteomic changes in Debaryomyces hansenii upon exposure to $\mathrm{NaCl}$ stress. FEMS Yeast Res. 7, 293-303.

Hu, Z., Chandran, K., Grasso, D., Smets, B.F., 2003. Impact of metal sorption and internalization on nitrification inhibition. Environ. Sci. Technol. 37, 728-734.

Johansson, T., Nyman, P.O., 1996. A cluster of genes encoding major isozymes of lignin peroxidase and manganese peroxidase from the white-rot fungus Trametes versicolor. Gene 170, 31-38.

Jolivalt, C., Madzak, C., Brault, A., Caminade, E., Malosse, C., Mougin, C., 2005. Expression of laccase IIIb from the white-rot fungus Trametes versicolor in the yeast Yarrowia lipolytica for environmental applications. Appl. Microbiol. Biotechnol. 66, 450-456.

Kähkönen, M.A., Lankinen, P., Hatakka, A., 2008. Hydrolytic and ligninolytic enzyme activities in the $\mathrm{Pb}$ contaminated soil inoculated with litter-decomposing fungi. Chemosphere 72, 708-714.

Keshri, G., Magan, N., 2000. Detection and differentiation between mycotoxigenic and non-mycotoxigenic strains of two Fusarium spp. using volatile production profiles and hydrolytic enzymes. J. Appl. Microbiol. 89, 825-833.

Kim, Y., Nandakumar, M.P., Marten, M.R., 2007. Proteomics of filamentous fungi. Trends Biotechnol. 25, 395-400.

Kjøller, A.H., Struwe, S., 2002. Fungal communities, succession, enzymes, and decomposition. In: Burns, R.G., Dick, R.P. (Eds.), Enzymes in the Environment. Marcel Dekker Inc., New York, pp. 267-284.

Kollmann, A., Boyer, F.D., Ducrot, P.H., Kerhoas, L., Jolivalt, C., Touton, I., Einhorn, J., Mougin, C., 2005. Oligomeric compounds formed from 2,5-xylidine (2,5dimethylaniline) are potent enhancers of laccase production in Trametes versicolor ATCC 32745. Appl. Microbiol. Biotechnol. 68, 251-258.

Lesage-Meessen, L., Delattre, M., Haon, M., Thibault, J.F., Ceccaldi, B.C., Brunerie, P., Asther, M., 1996. A two-step bioconversion process for vanillin production from ferulic acid combining Aspergillus niger and Pycnoporus cinnabarinus. J. Biotechnol. 50, 107-113.

Liang, Y., Chen, H., Tang, M., Shen, S., 2007. Proteome analysis of an ectomycorrhizal fungus Boletus edulis under salt shock. Mycol. Res. 111, 939-946.

Mougin, C., Jolivalt, C., Briozzo, P., Madzak, C., 2003. Fungal laccases: from structure-activity studies to environmental applications. Envrion. Chem. Lett. 1, 145-148.

Necochea, R., Valderrama, B., Diaz-Sandoval, S., Folch-Mallol, J.L., Vazquez-Duhalt, R., Iturriaga, G., 2005. Phylogenetic and biochemical characterisation of a recombinant laccase from Trametes versicolor. FEMS Microbiol. Lett. 244, 235241.

Novotný, C., Cajthaml, T., Svobodová, K., Susla, M., Sasek, V., 2009. Irpex lacteus, a white-rot fungus with biotechnological potential-review. Folia Microbiol. 54, 375-390.

Paszczyňski, A., Huynh, V.B., Crawford, R., 1986. Comparison of liginnase-I and peroxidase-M2 from the white-rot fungus Phanerochaete chrysosporium. Arch. Biochem. Biophys. 244, 750-765.

van Gestel, C.A.M., 2008. Physico-chemical and biological parameters determine metal bioavailability in soils. Sci. Total Environ. 406, 385-395.

Wolfenden, B.S., Willson, R.L., 1982. Radical-cations as reference in kinetics studies of one-electron transfer reactions. J. Chem. Soc. Perkin Trans. 7, 805812.

Yoshitake, A., Katayama, Y., Nakamura, M., Iimura, Y., Kawai, S., Morohoshi, N., 1993. $\mathrm{N}$-linked carbohydrate chains protect laccase III from proteolysis in Coriolus versicolor. J. Gen. Microbiol. 139, 179-185. 